\title{
A ascensão comportamental do cirurgião
}

\section{The behavior upgrade of the surgeon}

\author{
TCBC/RS Fernando Pitrez
}

Inder dependente do crescimento científico, o cirurgião, assim como o médico em geral em sua longa atividade é passível de um processo evolutivo, muitas vezes inconsciente, que se reflete, no correr dos anos por um paulatino amadurecimento e uma benéfica sensatez no arrosto da cirurgia e no modo de encarar a dor e o padecimento gerados pela moléstia

No exato momento em que um jovem vestibulando, ainda no frescor da juventude, adentra no fascinante mundo da cirurgia associado às outras disciplinas, inicia-se, um processo de ascensão pessoal que só tem término no derradeiro ato médico.

O complexo e contínuo avanço da cirurgia segue uma árdua e sinuosa trilha, permeada por obstáculos desafiadores, que refletem no comportamento ético ,profissional e filosófico perante o enfermo e à enfermidade.

Esse percurso compõe-se de uma sucessão de etapas distintas progressivamente ascendentes do ponto de vista comportamental e do desempenho do próprio ofício. Iniciando-se na incerteza e insegurança advindas dos primeiros passos, segue-se uma fase de suposta onipotência, que tem prosseguimento em um período de amadurecimento e finalmente, um estágio derradeiro de humildade e plena consciência de si mesmo, de suas deficiências cirúrgicas e da missão primordial de agente na luta pela cura.

Como estudante, ainda não tem uma compreensão exata da nobreza da vocação que abraçou, preocupando-se apenas em alcançar um bom conceito nas múltiplas disciplinas curriculares e estágios práticos.

Poucos na época de formação acadêmica já atingem um patamar de entendimento tal que o faça vislumbrar a importância e o profundo significado do curso diferenciado e da especialidade a que se destinam. Uma parcela substantiva de acadêmicos inclusive vislumbram a futura especialidade cirúrgica apenas como uma forma de alcançar sucesso financeiro e social. Uma visão equivocada levada mais à juventude e à inexperiência. Essa perspectiva distorcida somente dará lugar à inóspita realidade quando, mais tarde quando chegar à conclusão inevitável de que o encargo a que se destinam é muito mais uma vocação diferenciada do que propriamente uma profissão.

A insegurança dos primeiros atos operatórios e decisões, conforme o diploma ostentado com orgulho, que o habilita legalmente a exercer o nobre missão de "operar para salvar", é comum e passageira.

Mais tarde, à medida em que se torna mais seguro na prática cirúrgica , a inação incipiente cede lugar a uma ilusória sensação de poder diante da enfermidade.
Instintivamente tende a colocar-se em um patamar superior aos eventuais pacientes por considerar-se à margem da fragilidade humana, infenso à doença. E capaz de tudo resolver com a lâmina afiada de um bisturi. Para ele, como ilusoriamente julga ter uma vara de condão salvadora, a dor sofrimento são apanágios somente dos pacientes que dependem de seu mágico poder de cura.

É preciso ,nessa fase, que o cirurgião tenha uma base sólida, moral e filosófica pois serão essas virtudes as que irão circunscrever indelevelmente a futura identidade no árido campo da cirurgia.

Como é sabido e facilmente comprovado, no desenvolvimento do ser humano todas as sensações e vivências, desde as primeiras e mais antigas, permanecem indelevelmente gravadas no inconsciente. Quando, mais tarde, acionadas por um estímulo qualquer, afloram à superfície cerebral, influindo decisivamente sobre o comportamento atual.

No exercício da arte cirúrgica, observa-se um fenômeno psicológico semelhante. Mesmo em tempos bem mais tardios, as experiências e impressões iniciais vão-se refletir de maneira insofismável nas práticas futuras. O cirurgião atual, apesar da experiência e confiança adquiridas através dos anos, no âmago do seu íntimo, será o reflexo fiel do que foi no início de sua carreira. Raramente essa constatação deixa de seguir esse arquétipo. Reside aí, a relevância dos primeiros passos vacilantes do longo aprendizado da cirurgia.

Com o passar dos anos, o alvorecer da maturidade e o conseqüente acúmulo da experiência, aos poucos inicia um processo evolutivo distinto de transmutação de pensamentos, condutas e atitudes que se tornam mais precavidas e coerentes. Aqueles que exercitam a arte da reflexão produtiva começam a ter consciência clara da natural fragilidade do ser humano e das grandes limitações da própria cirurgia, apesar dos últimos avanços científicos e tecnológicos.

A respeito disso é lícito e adequado recordar as palavras de Júlio Sanderson, médico e escritor carioca, já falecido "o jovem médico está atolado no pragmatismo, com natural inclinação para o imediatismo... e se afasta um pouco da necessidade introspectiva de meditação e autocrítica". Sábias palavras que definem com sabedoria essa concepção.

A obsolescência de recursos diagnósticos tecnológicos é cada vez mais célere, prenunciando o alvorecer de um novo e fascinante paradigma cirúrgico baseado na emergente tecnologia, c aso da videolaparoscopia e, mais, recentemente, a cirurgia robótica, já uma realidade. 
Essas e outras inovações são promessas alvissareiras que alteram de modo radical a cirurgia atual e renovam conceitos e condutas até então tidos como definitivos e imutáveis. Os inventos já ultrapassam em muito o que sequer foi aclamado pelos mais argutos futurólogos.

Com tudo isso, deve o cirurgião de hoje estar consciente de sua condição diferenciada e procurar dentro das naturais limitações impostas ao ser humano, acompanhar essas inovações.

O fruto mais evidente desse desenvolvimento astronômico e rápido foi um dos fatores fundamentais no surgimento das múltiplas e complexas especialidade que são benéficas e bem-vindas. Não é lícito, na avançada quadra profissional dar-se conta do que no século XVII ,afirmou Ângelus Silesius (1614-1677): "Eu não sei o que sou, eu não sou o que sei".

Diante de tamanha magnitude, finalmente aflora a derradeira quadra do extenso e exaustivo ciclo de formação cirúrgica comportamental da formação cirúrgica : a humildade.

Corolário natural da experiência e da temperança, constituiu-se em um atributo essencial no reconhecimento das limitações intelectuais, físicas e temporais diante da magnitude do ato cirúrgico.

Ressalte-se que não se trata de uma humildade subserviente mas apenas o discernimento claro daquilo que é capaz cientificamente e manualmente dentro das naturais insuficiências humanas. Chega à percepção de que a missão derradeira é a de seguir a benemérita norma: "curar, quando viável, aliviar quando não for exequível e consolar sempre". Entende que,muito acima da perspectiva do lucro, o sacerdócio deve prevalecer. Nesse pensamento jamais abdica do conhecimento atualizado,nem tampouco da imprescindível destreza cirúrgica, em benefício do paciente, que deve ser o objetivo primordial de sua atividade.

Normalmente essa virtude floresce nessa fase mais adulta à medida em que se embrenha nos difíceis atos de diagnosticar, decidir e operar. Vem à percepção que não é demiurgo da vida e da morte, Apenas um privilegiado humano que devido ao sacrifício e abnegação, alcançou o sagrado direito de julgar e decidir eticamente ,muitas vezes sobre o destino do semelhante. Uma responsabilidade incomensurável para a qual infelizmente muitos não estão à altura pois para isso é preciso o despojamento dos ímpios instintos herdados de nossos ancestrais pré-históricos.

Embora extremamente dificultoso, aquele que porventura ousar atingir esse patamar de sinergia em relação ao exercício da cirurgia ,poderá considerar-se como um verdadeiro cirurgião na mais pura e completa acepção do termo. 